\title{
Alternative Anaphylactic Routes: The Potential Role of Macrophages
}

\author{
María M. Escribese ${ }^{1,2}$, Domenico Rosace1, Tomas Chivato², Tahia D. Fernández³, \\ Angel L. Corbi ${ }^{4}$ and Domingo Barber ${ }^{1 *}$
}

${ }^{1}$ Faculty of Medicine, IMMA Applied Molecular Medicine Institute, CEU San Pablo University, Madrid, Spain, ${ }^{2}$ Faculty of Medicine, Basic Medical Sciences Department, CEU San Pablo University, Madrid, Spain, ${ }^{3}$ Allergy Unit, Málaga Regional University Hospital-IBIMA, Málaga University, Málaga, Spain, ${ }^{4}$ Centro de Investigaciones Biológicas, CSIC, Madrid, Spain

\section{OPEN ACCESS}

Edited by:

Carlos Pastor Vargas, Instituto de Investigación

Sanitaria Fundacion

Jiménez Díaz, Spain

Reviewed by:

David Dombrowicz,

Institut national de la santé

et de la recherche médicale

(INSERM), France

Hugo Caire Castro-Faria-Neto,

Oswaldo Cruz Foundation, Brazil

*Correspondence:

Domingo Barber

domingo.barberhernandez@ceu.es

Specialty section: This article was submitted to Inflammation,

a section of the journal

Frontiers in Immunology

Received: 22 February 2017 Accepted: 18 April 2017

Published: 08 May 2017

Citation:

Escribese MM, Rosace D, Chivato T, Fernández TD, Corbí AL and

Barber D (2017) Alternative

Anaphylactic Routes:

The Potential Role of Macrophages.

Front. Immunol. 8:515.

doi: 10.3389/fimmu.2017.00515
Anaphylaxis is an acute, life-threatening, multisystem syndrome resulting from the sudden release of mediators from effector cells. There are two potential pathways for anaphylaxis. The first one, IgE-dependent anaphylaxis, is induced by antigen (Ag) cross-linking of Ag-specific IgE bound to the high-affinity lgE receptor (FceRI) on mast cells and basophils. The second one, IgG-dependent anaphylaxis is induced by Ag cross-linking of Ag-specific lgG bound to lgG receptors (FcyRI, FcyRIIA, FcyRIIB, FcyRIIC, and FcyRIIIA) on macrophages, neutrophils, and basophils. Macrophages exhibit a huge functional plasticity and are capable of exerting their scavenging, bactericidal, and regulatory functions under a wide variety of tissue conditions. Herein, we will review their potential role in the triggering and development of anaphylaxis. Thereby, macrophages, among other immune cells, play a role in both anaphylactic pathways (1) by responding to anaphylactic mediators secreted by mast cells after specific lgE cross-linking or (2) by acting as effector cells in the anaphylactic response mediated by IgG. In this review, we will go over the cellular and molecular mechanisms that take place in the above-mentioned anaphylactic pathways and will discuss the clinical implications in human allergic reactions.

Keywords: anaphylaxis, IgG, IgE, macrophages, serotonin

\section{PATHWAY FOR ANAPHYLAXIS: IgE AND IgG DEPENDENT}

IgE-mediated anaphylaxis is well established and is thought to be the main anaphylactic pathway. However, increasing evidence obtained from animal models supports the existence of a second pathway. In this IgG-dependent pathway, macrophages instead of mast cells, and IgGs rather than IgE, are the immunoglobulins involved, and the main mediator released is platelet-activating factor (PAF) instead of histamine. Differences were detailed in Table 1. Data from IgG-mediated anaphylaxis were recopilated mainly from previous murine models, while data from IgE-mediated anaphylaxis were obtained from both animal and human previous reports (Table 1).

In this review, we will analyze the evidence obtained from murine experimental models supporting the existence of an IgG-dependent anaphylaxis pathway and speculated about the possibility of a similar mechanism in humans, either as a stand-alone pathway or as a synergistic mechanism to IgE-mediated anaphylaxis.

The main body of evidence for IgG-mediated anaphylaxis comes from animal models.

Passive immunization, result of the administration of specific Igs, followed by enteral or parenteral challenge with the appropriate antigen $(\mathrm{Ag})$ supported the relevance of $\operatorname{IgE}$ and mast cells in the development of anaphylaxis (1-3). Indeed, animals with depleted mast cells, IgE or FceRI, subjected 
TABLE 1 | Main features in the mechanisms and triggering factors involved in IgE- and IgG-dependent anaphylactic pathways.

\begin{tabular}{|c|c|c|}
\hline & $\begin{array}{l}\text { IgE-dependent } \\
\text { pathway }\end{array}$ & IgG-dependent pathway \\
\hline Ig involved & $\lg E$ & lgGs \\
\hline Antigen concentration & Low & High \\
\hline Fc receptor & $\mathrm{F}_{\mathrm{C} \varepsilon \mathrm{RI}}$ & 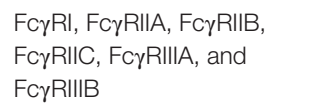 \\
\hline Effector cells & Mast cells & $\begin{array}{l}\text { Macrophages, monocytes, } \\
\text { and neutrophils }\end{array}$ \\
\hline Mediators & $\begin{array}{l}\text { Histamine (leukotrienes, } \\
\text { prostaglandin, } \\
\text { serotonin, etc.) }\end{array}$ & $\begin{array}{l}\text { Platelet-activating factor } \\
\text { (leukotrienes, prostaglandin, } \\
\text { serotonin, etc.) }\end{array}$ \\
\hline Triggering factors & $\begin{array}{l}\text { Food, drugs } \\
\text { (e.g., beta-lactam } \\
\text { antibiotics), insect sting } \\
\text { and bites, exercise } \\
\text { (food dependent) }\end{array}$ & $\begin{array}{l}\text { Food, drugs [monoclonal } \\
\text { antibodies (omalizumab or } \\
\text { infliximab)], or dextrans, others }\end{array}$ \\
\hline
\end{tabular}

to active or passive immunization followed by oral challenge, completely suppress the anaphylactic reaction.

However, animal immunization followed parental challenge with the same Ag, revealed that anaphylaxis could even occur in the absence of the IgE/FceRI/mast cell pathway. This demonstrates the existence of an alternative anaphylaxis pathway that closely resembles IgE-mediated anaphylaxis but involves other key players (3-5).

Both pathways display significant differences in their main features (Table 1), such as the requirement of different concentrations of $\mathrm{Ag}$ and $\mathrm{Ab}$ to induce the reaction.

In fact, studies comparing Ag doses required to elicit IgE- or IgG-mediated anaphylaxis suggested that the IgG-dependent pathway requires approximately 100 -fold more $\mathrm{Ag}$ than the $\operatorname{IgE}$ pathway to induce a similar response (3).

Additionally, anaphylaxis mediated through IgG also appeared to require much more $\mathrm{Ab}$ than anaphylaxis mediated through IgE. In fact, IgE-mediated anaphylaxis can even be seen with serologically undetected sIgE levels, in which sIgE bound to mast cells is sufficient (5). In contrast, relatively high levels of serum IgG are required for Ag induction of anaphylaxis through the IgG pathway (3). This could be due to two factors: first, the much higher affinity of FceRI for IgE than Fc $\gamma$ RIII for IgG, and second, the fact that IgE binds directly to mast cell-associated IgE, whereas $\mathrm{Ag} / \mathrm{IgG}$ complexes are presumably formed in blood and lymph before binding by FcyRIII on other immune cells such as macrophages $(6,7)$.

In the case of IgG-mediated anaphylaxis, the immunoglobulin subclasses and receptors involved in the reaction also play an important role. Regarding IgG subclasses, IgG1, IgG2a, and IgG2b have been reported to enable the induction of systemic anaphylaxis, inducing mild to severe hypothermia $(8,9)$. Furthermore, IgGs can bind to six different Fc $\gamma$ R, namely, Fc $\gamma$ RI, Fc $\gamma$ RIIA, Fc $\gamma$ RIIB, Fc $\gamma$ RIIC, Fc $\gamma$ RIIIA, and Fc $\gamma$ RIIIB, which have different affinities, downstream signaling routes, and patterns of expression $(10,11)$. Fc $\gamma$ RI is considered as the high-affinity receptor, although FcyRIIIB can bind IgG with high and low affinity depending on the IgG subclass (7).

Another crucial issue for development of either the IgE or IgG pathways of anaphylaxis is the balance between Ag concentration and the levels of IgG or IgE. Usually, both Ag-specific IgE and IgG are present in blood, with IgG levels being higher. Under these conditions, Ag will encounter IgG in blood before it can bind to mast cell-associated IgE, which results in blockage of IgE-mediated anaphylaxis. However, when Ag levels are insufficient to induce IgG-mediated anaphylaxis, high levels of IgG can prevent the development of any anaphylactic response. For a similar reason, larger amounts of Ag trigger anaphylaxis predominantly through the alternative pathway when Ag-specific IgG antibody levels are high, even though Ag-specific IgE is present. In this situation, the anaphylactic pathways will only be triggered simultaneously when the amount of challenge Ag exceeds the capacity of IgG antibody to block Ag binding to mast cell-associated $\operatorname{IgE}(5)$.

Taken together, these data clearly support significant differences between both anaphylactic pathways regarding the type of Ig as well as the conditions needed for the development of one pathway or the other (Figure 1). However, in humans the relevance of the alternative pathway is still a matter of debate.

\section{EFFECTOR CELLS AND MEDIATORS INVOLVED IN IgE- AND IgG-MEDIATED ANAPHYLAXIS}

There is complete segregation of the effector cells and mediators underlying both anaphylactic pathways.

While it is well known that the IgE-dependent pathway of anaphylaxis is triggered by an allergen interacting with allergenspecific IgE bound to the FceRI on mast cells, which leads to cross-linking and subsequent degranulation of the cells, the exact mechanism underlying the $\operatorname{IgG}$ anaphylactic pathway has not been completely elucidated. In fact, there is significant controversy about the effector cells involved in IgG-mediated anaphylaxis, and it seems that the main effector cells, at least in murine experimental models are macrophages/monocytes and basophils. However, some authors also suggest a role for neutrophils (8) and basophils (12). In fact, the latest publication of Khodoun et al., covering all three known effector cell types, concluded that all cells, monocytes/macrophages, basophils, and neutrophils, participate in IgG-induced anaphylaxis (13).

Another point of controversy is the level of FcyR expression and the type of myeloid cell expressing the receptor. In this regard, Beutier et al. showed that the differential expression of inhibitory Fc $\gamma$ RIIB on myeloid cells and its differential binding of IgG subclasses control the contribution of basophils, neutrophils, and monocytes to IgG-dependent anaphylaxis, thus revealing novel complexities in cell population regulation mechanisms and, therefore, their relative contribution to IgG-induced reactions in murine models (14).

The outcome of this process of $\mathrm{Ab}$-receptor recognition and subsequent cellular signaling activation is the release of several 


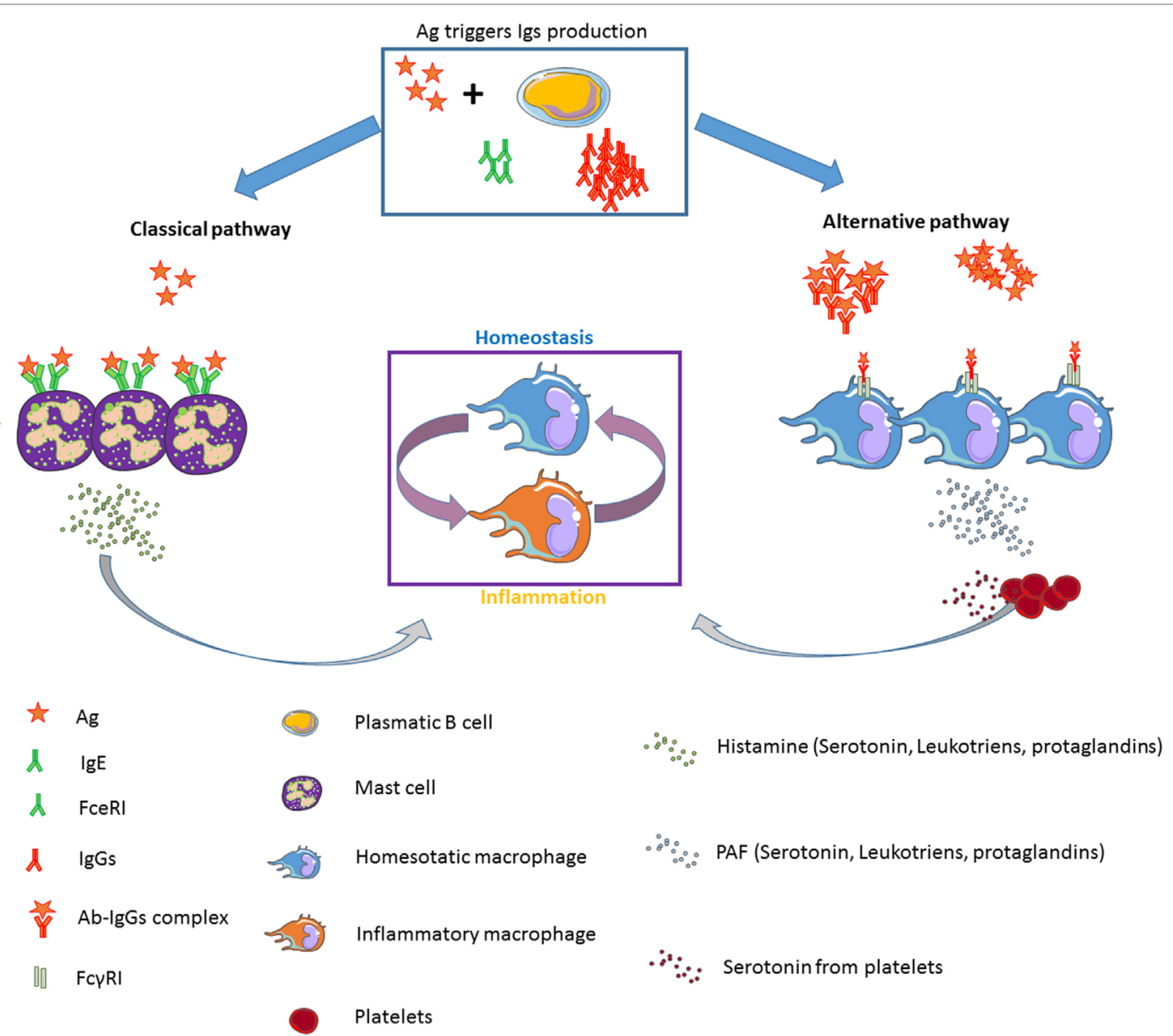

FIGURE 1 | Diagram showing the classical (IgE-dependent) and alternative (IgG-dependent) anaphylactic pathways: effector cells, mediators, Igs, and FcR implicated.

mediators responsible for the hypothermia and hypotension that characterize anaphylaxis.

The main mediator involved in IgE-mediated anaphylaxis is histamine. Histamine is known to play an essential role in the evolution of the anaphylactic process (15-17). Moreover, it is also involved in regulation of the immune response $(18,19)$. Other mediators released during IgE-mediated anaphylaxis are prostaglandins and leukotrienes $(17,20)$. Furthermore, a receptor for prostaglandins has also been described in several immune cells, such as macrophages or innate lymphoid cells (ILC2) (21).

Another significant metabolite reported to be released by mast cells upon IgE cross-linking is serotonin (22-24). The role of serotonin in the anaphylactic process is still unknown, although recent reports have suggested that this metabolite is key in immune response regulation $(23,25)$ and, more specifically, in the regulation of macrophage polarization and inflammatory resolution (26, 27), allergy (28), and hypotension (29). Serotonin participation in the regulation of inflammation and immune response upon anaphylaxis will be further discussed.

In the case of IgG-mediated anaphylaxis, the main mediator is $\operatorname{PAF}(5,30,31)$. It has been reported that serum PAF levels correlate with the severity of anaphylaxis (32). This metabolite is produced and secreted by several types of cells and is active at concentrations as low as $10^{-12} \mathrm{~mol} / \mathrm{L}$ despite its short half-life (32).

Platelet-activating factor (PAF) is implicated in platelet aggregation and activation through the release of vasoactive amine during inflammatory responses, thus resulting in an increase in vascular permeability, circulatory collapse, a decreased cardiac output, and other biological effects (33).

Strikingly, platelets have been reported to be the major reservoirs of serotonin outside the nervous system (34), once again suggesting a novel role for serotonin in progression of the anaphylactic pathway as well as in allergic disease progression.

\section{MACROPHAGES AND SEROTONIN: POTENTIAL NOVEL PLAYERS IN ANAPHYLAXIS?}

In anaphylaxis, macrophages have been described as effector cells in the IgG-dependent pathway, since they express Fc $\gamma \mathrm{R}$ and release PAF. This has been demonstrated in mouse models of 
anaphylaxis. Apart from this, no specific role has been described for these immune cells in IgE-dependent anaphylaxis in neither human nor mice. However, one could speculate that all the mediators released by mast cells (histamine, leukotrienes, and prostaglandin) might significantly affect macrophage polarization status and, thus, immune response outcome. These mechanisms will probably occur in both mouse and humans.

Macrophages and dendritic cells occupy a prominent position during immune responses, being essential for their initiation (a function primarily displayed by dendritic cells) and for the final effector phases (mostly macrophages) (35). In fact, and regardless of the triggering stimulus, macrophages are usually the final effectors of any given immune response, because they can acquire a continuum of functional states, thus adapting their effector functions to the surrounding environment and to the prevailing $\mathrm{T}$ cell-derived cytokines in the extracellular milieu receptor signals (36). By virtue of this plasticity, macrophages are not only critical for maintaining tissue homeostasis but can either display pro- or anti-inflammatory functions, promote or resolve an inflammatory response, and cause tissue damage or help in tissue repair. Results generated in recent years have clearly established the widespread homeostatic functions of macrophages, as they fine-tune physiological parameters as relevant as body temperature and even transit time in the gut (37-39).

Regarding factors with a prominent role in macrophage polarization and anaphylaxis, serotonin has also been shown to modify macrophage polarization in the phenotypic, cytokine, and transcriptional profile (27). Besides its production by mast cells (40), peripheral serotonin is mostly produced by enterochromaffin cells and later stored by platelets in dense granules (34). Serotonin not only promotes proliferation of numerous cell types but also functions as a regulator of immune and inflammatory responses. In fact, the immunomodulatory activity of serotonin is partly mediated through direct actions on macrophages: serotonin favors angiogenesis in colon cancer allografts by acting on tumor-infiltrating macrophages (41), contributes to pulmonary arterial hypertension by altering myeloid cell differentiation potential (42), and limits postoperative bowel inflammation via recognition by muscularis and peritoneal macrophages (43). At the molecular level, these actions appear to be mediated by serotonin receptors expressed on the macrophage cell surface. We have previously demonstrated that human anti-inflammatory macrophages specifically express HTR2B and HTR7 serotonin receptors, whose ligation results in altered macrophage transcriptome and inhibition of pro-inflammatory cytokine production (27). In fact, serotonin appears to switch the macrophage transcriptome toward a growth-promoting, anti-inflammatory, and pro-fibrotic gene profile, whose acquisition depends on both HTR2B and HTR7 (27). Therefore, we can speculate that agonists/antagonists of serotonin receptors might be therapeutically useful for limiting the uncontrolled production of pro-inflammatory cytokines that takes place in chronic inflammatory diseases (44). Surprisingly, HTR7 is the receptor responsible for serotonin-induced hypothermia (45), but whether macrophage HTR7 contributes to this response is currently unknown.
A reasonable hypothesis for the role of serotonin in the IgG-mediated anaphylaxis might be the generation of a feedback loop that favors the acquisition of an anti-inflammatory phenotype by macrophages right after the induction of an anaphylactic shock, aiming to restore homeostatic conditions (Figure 1).

Another strategy in line with the alternative anaphylactic pathway in humans that also supports the connection between changes in IgG concentration and a regulation of macrophages polarization is treatment with intravenous immunoglobulins (IVIg). IVIg is a preparation of polyclonal poly-specific IgG from the plasma of thousands of donors that is currently used as immunoregulatory and anti-inflammatory treatment in autoimmune and inflammatory disorders (46). The mechanism of action of IVIg has not been completely elucidated, but we have reported that IVIg skews human and mouse macrophage polarization through FcrR-dependent mechanisms (47). IVIg immunomodulatory activity is dependent on the macrophage polarization state, as it limits the pro-inflammatory nature of GM-CSF-dependent macrophages and favors the acquisition of pro-inflammatory properties in anti-inflammatory macrophages (47). In fact, IVIg enhances inflammatory tissue-damaging responses in murine models of stroke and sepsis and reduces tumor growth and metastasis by shifting the polarization state of tumor-associated myeloid cells toward the pro-inflammatory side (47). Since the latter effect was dependent on the expression of Fc receptors, we can conclude that ligation of molecules, such as $\mathrm{CD} 16$ and $\mathrm{FcR} \gamma$, might be useful targets for the modulation of macrophage polarization.

\section{EVIDENCE FOR IgG-MEDIATED ANAPHYLAXIS IN HUMAN}

The existence of IgG-mediated anaphylaxis in humans is not clear. In spite of a lack of direct evidence, the findings of some studies imply a possible alternative mechanism to IgE-mediated anaphylaxis $(5,30)$. PAF, which seems to be associated with the IgG mechanism in mice, is an essential mediator in human anaphylaxis, and its levels are elevated in patients undergoing anaphylaxis compared with a control group (48). The catabolism of this mediator is controlled by the enzyme PAF acetylhydrolase (PAF-AH), which is in charge of PAF inactivation (49). Some studies have correlated the levels of these two markers with the severity of anaphylaxis, with increases in PAF levels and decreases in PAF-AH activity. Moreover, patients with the lowest levels of PAF-AH activity were found to exhibit a 27-times higher risk of developing severe or fatal anaphylaxis than patients with normal levels $(48,50)$.

Several cases of drug anaphylaxis are classified as non-allergic due to the absence of specific IgE titers (measured in sera or by skin test) and the lack of increased serum tryptase or basophil activation (51), although no study has addressed the IgG-mediated mechanism in these patients.

However, in patients treated with biological drugs, these can induce anaphylaxis without the presence of detectable specific IgE, although they do present high levels of specific IgG (52). 
This observation derives from patients with IgA deficiency who developed anaphylaxis after receiving a blood transfusion or treatment with intravenous injections of IgA. In these subjects, increased levels of IgG anti-IgA antibodies were also found $(53,54)$.

Moreover, in a later study patients with higher levels of IgG were found to present an increased frequency of a gain-offunction allele of the stimulatory FcyRIIA (55), although this study was conducted in a limited number of subjects.

The presence of increased titers of specific IgG has also been observed in patients treated with human, humanized, or chimeric mAbs, such as infliximab or adalimumab (56), and other biological factors (57-59). In the case of infliximab, the presence of high levels of specific IgG has been related to an increased risk of suffering anaphylaxis (60). A common factor to all these reported cases was the administration of high quantities of the suspected Ag, leading to the presence of high levels of specific IgG.

As with drug allergies, evidence for the existence of IgGmediated anaphylaxis has also been found in cases of food allergy, especially in anaphylaxis induced by lipid transfer proteins (LTP). Increased levels of anti-LTP IgG1 and IgG3 and increased expression of the three genes coding for the activating receptor Fc $\gamma \mathrm{RI}$ (CD64) have been observed in a group of patients with food anaphylaxis induced by LTP (61). Mast cells can be activated by IgG via this receptor $(62,63)$ and are able to recognize both IgG1 and IgG3 with high affinity $(64,65)$. Interestingly, both anti-LTP specific IgG and IgE have been found in LTP allergic patients, which could suggest an involvement of both pathways in the anaphylactic mechanism in these subjects (61). The most severe food allergens are milk, egg, and peanut, and all of them share a high allergenic concentration, thus fulfilling the criteria necessary to elicit an alternative anaphylactic pathway.

\section{REFERENCES}

1. Kucuk ZY, Strait R, Khodoun MV, Mahler A, Hogan S, Finkelman FD. Induction and suppression of allergic diarrhea and systemic anaphylaxis in a murine model of food allergy. J Allergy Clin Immunol (2012) 129(5):1343-8. doi:10.1016/j.jaci.2012.03.004

2. Strait RT, Mahler A, Hogan S, Khodoun M, Shibuya A, Finkelman FD. Ingested allergens must be absorbed systemically to induce systemic anaphylaxis. J Allergy Clin Immunol (2011) 127(4):982-9.e1. doi:10.1016/j.jaci.2011.01.034

3. Strait RT, Morris SC, Finkelman FD. IgG-blocking antibodies inhibit IgEmediated anaphylaxis in vivo through both antigen interception and Fc gamma RIIb cross-linking. J Clin Invest (2006) 116(3):833-41. doi:10.1172/ JCI25575

4. Jiao D, Liu Y, Lu X, Liu B, Pan Q, Zhu P, et al. Macrophages are the dominant effector cells responsible for IgG-mediated passive systemic anaphylaxis challenged by natural protein antigen in BALB/c and C57BL/6 mice. Cell Immunol (2014) 289(1-2):97-105. doi:10.1016/j.cellimm.2014.03.018

5. Finkelman FD, Khodoun MV, Strait R. Human IgE-independent systemic anaphylaxis. J Allergy Clin Immunol (2016) 137(6):1674-80. doi:10.1016/j. jaci.2016.02.015

6. Kinet JP. The high-affinity IgE receptor (Fc epsilon RI): from physiology to pathology. Annu Rev Immunol (1999) 17:931-72. doi:10.1146/annurev. immunol.17.1.931

7. Nimmerjahn F, Ravetch JV. Divergent immunoglobulin G subclass activity through selective Fc receptor binding. Science (2005) 310(5753):1510-2. doi:10.1126/science.1118948

\section{CONCLUSION AND FURTHER EXPECTATIONS}

Anaphylaxis is the most serious allergic reaction that can occur and may even endanger the patient's life. Moreover, epidemiological data indicate that cases of anaphylaxis are increasing worldwide. The mechanisms involved in the pathogenesis of anaphylaxis can be immunological or non-immunological. Classical immunological reactions mediated by IgE are observed in food anaphylaxis, beta-lactam antibiotics, or hymenopteran stings. Immunological reactions mediated by $\operatorname{IgG}$ are being observed following administration of certain monoclonal antibodies (omalizumab or infliximab) or dextrans. The role of macrophages is relevant in this type of IgG-mediated immunological anaphylaxis. PAF released by activated macrophages can activate mast cells, explaining the pathogenesis of this anaphylaxis. Given the increased use of different monoclonal antibodies in clinical practice for the treatment of immune-based diseases, an increase in this type of IgG-mediated anaphylaxis might be observed.

\section{AUTHOR CONTRIBUTIONS}

All the authors have participated in the writing of the manuscript. DB has written, organized, and revised the manuscript.

\section{FUNDING}

This work was supported by ISCIII (project numbers PI16/00249 and PI15/02256) cofounded by FEDER for the thematic network and cooperative research centers ARADyALRD16/0006/0015 and $\mathrm{RD} 16 / 0006 / 0001$. This work was also supported by the Ministry of Economy and Competitiveness (project number SAF201452423-R) and by Fundación Mutua Madrileña (AP158912015). DR and was supported by FPI-CEU predoctoral fellowships.

8. Jonsson F, Mancardi DA, Kita Y, Karasuyama H, Iannascoli B, Van Rooijen N, et al. Mouse and human neutrophils induce anaphylaxis. J Clin Invest (2011) 121(4):1484-96. doi:10.1172/JCI45232

9. Miyajima I, Dombrowicz D, Martin TR, Ravetch JV, Kinet JP, Galli SJ. Systemic anaphylaxis in the mouse can be mediated largely through IgG1 and Fc gammaRIII. Assessment of the cardiopulmonary changes, mast cell degranulation, and death associated with active or IgE- or IgG1-dependent passive anaphylaxis. J Clin Invest (1997) 99(5):901-14. doi:10.1172/ JCI1 19255

10. Bournazos S, Ravetch JV. Fcgamma receptor pathways during active and passive immunization. Immunol Rev (2015) 268(1):88-103. doi:10.1111/ imr. 12343

11. DiLillo DJ, Ravetch JV. Fc-receptor interactions regulate both cytotoxic and immunomodulatory therapeutic antibody effector functions. Cancer Immunol Res (2015) 3(7):704-13. doi:10.1158/2326-6066.CIR-15-0120

12. Tsujimura Y, Obata K, Mukai K, Shindou H, Yoshida M, Nishikado H, et al. Basophils play a pivotal role in immunoglobulin-G-mediated but not immunoglobulin-E-mediated systemic anaphylaxis. Immunity (2008) 28(4): 581-9. doi:10.1016/j.immuni.2008.02.008

13. Khodoun MV, Kucuk ZY, Strait RT, Krishnamurthy D, Janek K, Clay CD, et al. Rapid desensitization of mice with anti-FcgammaRIIb/FcgammaRIII $\mathrm{mAb}$ safely prevents IgG-mediated anaphylaxis. J Allergy Clin Immunol (2013) 132(6):1375-87. doi:10.1016/j.jaci.2013.09.008

14. Beutier H, Gillis CM, Iannascoli B, Godon O, England P, Sibilano R, et al. IgG subclasses determine pathways of anaphylaxis in mice. J Allergy Clin Immunol (2016). doi:10.1016/j.jaci.2016.03.028 
15. Wang M, Han J, Domenico J, Shin YS, Jia Y, Gelfand EW. Combined blockade of the histamine $\mathrm{H} 1$ and $\mathrm{H} 4$ receptor suppresses peanut-induced intestinal anaphylaxis by regulating dendritic cell function. Allergy (2016) 71(11): 1561-74. doi:10.1111/all.12904

16. Hox V, O'Connell MP, Lyons JJ, Sackstein P, Dimaggio T, Jones N, et al. Diminution of signal transducer and activator of transcription 3 signaling inhibits vascular permeability and anaphylaxis. J Allergy Clin Immunol (2016) 138(1):187-99. doi:10.1016/j.jaci.2015.11.024

17. Peavy RD, Metcalfe DD. Understanding the mechanisms of anaphylaxis. Curr Opin Allergy Clin Immunol (2008) 8(4):310-5. doi:10.1097/ACI. 0b013e3283036a90

18. Aldinucci A, Bonechi E, Manuelli C, Nosi D, Masini E, Passani MB, et al. Histamine regulates actin cytoskeleton in human toll-like receptor 4-activated monocyte-derived dendritic cells tuning CD4+ T lymphocyte response. J Biol Chem (2016) 291(28):14803-14. doi:10.1074/jbc.M116.720680

19. Carroll-Portillo A, Cannon JL, te Riet J, Holmes A, Kawakami Y, Kawakami T, et al. Mast cells and dendritic cells form synapses that facilitate antigen transfer for T cell activation. J Cell Biol (2015) 210(5):851-64. doi:10.1083/ jcb.201412074

20. Nassiri M, Eckermann O, Babina M, Edenharter G, Worm M. Serum levels of 9alpha,11beta-PGF2 and cysteinyl leukotrienes are useful biomarkers of anaphylaxis. J Allergy Clin Immunol (2016) 137(1):312-4. doi:10.1016/j. jaci.2015.07.001

21. Karta MR, Broide DH, Doherty TA. Insights into group 2 innate lymphoid cells in human airway disease. Curr Allergy Asthma Rep (2016) 16(1):8. doi:10.1007/s11882-015-0581-6

22. Modena BD, Dazy K, White AA. Emerging concepts: mast cell involvement in allergic diseases. Transl Res (2016) 174:98-121. doi:10.1016/j.trsl.2016.02.011

23. Conti P, Shaik-Dasthagirisaheb YB. Mast cell serotonin immunoregulatory effects impacting on neuronal function: implications for neurodegenerative and psychiatric disorders. Neurotox Res (2015) 28(2):147-53. doi:10.1007/ s12640-015-9533-0

24. Theoharides TC, Alysandratos KD, Angelidou A, Delivanis DA, Sismanopoulos N, Zhang B, et al. Mast cells and inflammation. Biochim Biophys Acta (2012) 1822(1):21-33. doi:10.1016/j.bbadis.2010.12.014

25. Arreola R, Becerril-Villanueva E, Cruz-Fuentes C, Velasco-Velazquez MA, Garces-Alvarez ME, Hurtado-Alvarado G, et al. Immunomodulatory effects mediated by serotonin. J Immunol Res (2015) 2015:354957. doi:10.1155/ 2015/354957

26. de Las Casas-Engel M, Corbi AL. Serotonin modulation of macrophage polarization: inflammation and beyond. Adv Exp Med Biol (2014) 824:89-115. doi:10.1007/978-3-319-07320-0_9

27. de las Casas-Engel M, Dominguez-Soto A, Sierra-Filardi E, Bragado R, Nieto C, Puig-Kroger A, et al. Serotonin skews human macrophage polarization through HTR2B and HTR7. J Immunol (2013) 190(5):2301-10. doi:10.4049/ jimmunol.1201133

28. Idzko M, Pitchford S, Page C. Role of platelets in allergic airway inflammation. J Allergy Clin Immunol (2015) 135(6):1416-23. doi:10.1016/j.jaci.2015.04.028

29. Fraer M, Kilic F. Serotonin: a different player in hypertension-associated thrombosis. Hypertension (2015) 65(5):942-8. doi:10.1161/HYPERTENSIONAHA. 114.05061

30. Munoz-Cano R, Picado C, Valero A, Bartra J. Mechanisms of anaphylaxis beyond IgE. J Investig Allergol Clin Immunol (2016) 26(2):73-82; quiz 2p following 3. doi:10.18176/jiaci.0046

31. Finkelman FD. Anaphylaxis: lessons from mouse models. JAllergy Clin Immunol (2007) 120(3):506-15; quiz 16-7. doi:10.1016/j.jaci.2007.07.033

32. Gill P, Jindal NL, Jagdis A, Vadas P. Platelets in the immune response: revisiting platelet-activating factor in anaphylaxis. J Allergy Clin Immunol (2015) 135(6):1424-32. doi:10.1016/j.jaci.2015.04.019

33. Venable ME, Zimmerman GA, McIntyre TM, Prescott SM. Platelet-activating factor: a phospholipid autacoid with diverse actions. JLipid Res (1993) 34(5):691-702.

34. Yano JM, Yu K, Donaldson GP, Shastri GG, Ann P, Ma L, et al. Indigenous bacteria from the gut microbiota regulate host serotonin biosynthesis. Cell (2015) 161(2):264-76. doi:10.1016/j.cell.2015.02.047

35. Sica A, Mantovani A. Macrophage plasticity and polarization: in vivo veritas. J Clin Invest (2012) 122(3):787-95. doi:10.1172/JCI59643

36. Mosser DM, Edwards JP. Exploring the full spectrum of macrophage activation. Nat Rev Immunol (2008) 8(12):958-69. doi:10.1038/nri2448
37. Wynn TA, Chawla A, Pollard JW. Macrophage biology in development, homeostasis and disease. Nature (2013) 496(7446):445-55. doi:10.1038/ nature 12034

38. Nguyen KD, Qiu Y, Cui X, Goh YP, Mwangi J, David T, et al. Alternatively activated macrophages produce catecholamines to sustain adaptive thermogenesis. Nature (2011) 480(7375):104-8. doi:10.1038/nature10653

39. Muller PA, Koscso B, Rajani GM, Stevanovic K, Berres ML, Hashimoto D, et al. Crosstalk between muscularis macrophages and enteric neurons regulates gastrointestinal motility. Cell (2014) 158(2):300-13. doi:10.1016/j. cell.2014.04.050

40. Kushnir-Sukhov NM, Brown JM, Wu Y, Kirshenbaum A, Metcalfe DD. Human mast cells are capable of serotonin synthesis and release. J Allergy Clin Immunol (2007) 119(2):498-9. doi:10.1016/j.jaci.2006.09.003

41. Nocito A, Dahm F, Jochum W, Jang JH, Georgiev P, Bader M, et al. Serotonin regulates macrophage-mediated angiogenesis in a mouse model of colon cancer allografts. Cancer Res (2008) 68(13):5152-8. doi:10.1158/0008-5472. CAN-08-0202

42. Launay JM, Herve P, Callebert J, Mallat Z, Collet C, Doly S, et al. Serotonin 5-HT2B receptors are required for bone-marrow contribution to pulmonary arterial hypertension. Blood (2012) 119(7):1772-80. doi:10.1182/ blood-2011-06-358374

43. Tsuchida Y, Hatao F, Fujisawa M, Murata T, Kaminishi M, Seto Y, et al. Neuronal stimulation with 5-hydroxytryptamine 4 receptor induces anti-inflammatory actions via alpha7nACh receptors on muscularis macrophages associated with postoperative ileus. Gut (2011) 60(5):638-47. doi:10.1136/gut.2010. 227546

44. Chabbi-Achengli Y, Coman T, Collet C, Callebert J, Corcelli M, Lin H, et al. Serotonin is involved in autoimmune arthritis through Th17 immunity and bone resorption. Am JPathol (2016) 186(4):927-37. doi:10.1016/j. ajpath.2015.11.018

45. Hedlund PB, Danielson PE, Thomas EA, Slanina K, Carson MJ, Sutcliffe JG. No hypothermic response to serotonin in 5-HT7 receptor knockout mice. Proc Natl Acad Sci U S A (2003) 100(3):1375-80. doi:10.1073/pnas.0337340100

46. Gelfand EW. Intravenous immune globulin in autoimmune and inflammatory diseases. N Engl J Med (2012) 367(21):2015-25. doi:10.1056/NEJMra1009433

47. Dominguez-Soto A, de las Casas-Engel M, Bragado R, Medina-Echeverz J, Aragoneses-Fenoll L, Martin-Gayo E, et al. Intravenous immunoglobulin promotes antitumor responses by modulating macrophage polarization. J Immunol (2014) 193(10):5181-9. doi:10.4049/jimmunol.1303375

48. Vadas P, Gold M, Perelman B, Liss GM, Lack G, Blyth T, et al. Plateletactivating factor, PAF acetylhydrolase, and severe anaphylaxis. $N$ Engl J Med (2008) 358(1):28-35. doi:10.1056/NEJMoa070030

49. Stafforini DM. Biology of platelet-activating factor acetylhydrolase (PAF-AH, lipoprotein associated phospholipase A2). Cardiovasc Drugs Ther (2009) 23(1):73-83. doi:10.1007/s10557-008-6133-8

50. Brown SG, Stone SF, Fatovich DM, Burrows SA, Holdgate A, Celenza A, et al. Anaphylaxis: clinical patterns, mediator release, and severity. J Allergy Clin Immunol (2013) 132(5):1141-9.e5. doi:10.1016/j.jaci.2013.06.015

51. Farnam K, Chang C, Teuber S, Gershwin ME. Nonallergic drug hypersensitivity reactions. Int Arch Allergy Immunol (2012) 159(4):327-45. doi:10.1159/000339690

52. Cheifetz A, Smedley M, Martin S, Reiter M, Leone G, Mayer L, et al. The incidence and management of infusion reactions to infliximab: a large center experience. Am J Gastroenterol (2003) 98(6):1315-24. doi:10.1111/j.1572-0241. 2003.07457.x

53. Schmidt AP, Taswell HF, Gleich GJ. Anaphylactic transfusion reactions associated with anti-IgA antibody. N Engl J Med (1969) 280(4):188-93. doi:10.1056/NEJM196901232800404

54. Vassallo RR. Review: IgA anaphylactic transfusion reactions. Part I. Laboratory diagnosis, incidence, and supply of IgA-deficient products. Immunohematology (2004) 20(4):226-33.

55. van der Heijden J, Geissler J, van Mirre E, van Deuren M, van der Meer JW, Salama A, et al. A novel splice variant of FcgammaRIIa: a risk factor for anaphylaxis in patients with hypogammaglobulinemia. J Allergy Clin Immunol (2013) 131(5):1408-16.e5. doi:10.1016/j.jaci.2013.02.009

56. Steenholdt C, Svenson M, Bendtzen K, Thomsen OO, Brynskov J, Ainsworth MA. Acute and delayed hypersensitivity reactions to infliximab and adalimumab in a patient with Crohn's disease. J Crohns Colitis (2012) 6(1):108-11. doi:10.1016/ j.crohns.2011.08.001 
57. Hedin H, Richter W, Messmer K, Renck H, Ljungstrom KG, Laubenthal H. Incidence, pathomechanism and prevention of dextran-induced anaphylactoid/anaphylactic reactions in man. Dev Biol Stand (1980) 48:179-89.

58. Umeda Y, Fukumoto Y, Miyauchi T, Imaizumi M, Shimabukuro K, Mori Y, et al. [Anaphylactic shock related to aprotinin induced by anti-aprotinin immunoglobulin G antibody alone; report of a case]. Kyobu Geka (2007) 60(1):69-71.

59. Bergamaschini L, Mannucci PM, Federici AB, Coppola R, Guzzoni S, Agostoni A. Posttransfusion anaphylactic reactions in a patient with severe von Willebrand disease: role of complement and alloantibodies to von Willebrand factor. J Lab Clin Med (1995) 125(3):348-55.

60. Miele E, Markowitz JE, Mamula P, Baldassano RN. Human antichimeric antibody in children and young adults with inflammatory bowel disease receiving infliximab. J Pediatr Gastroenterol Nutr (2004) 38(5):502-8. doi:10.1097/00005176-200405000-00008

61. Munoz-Cano R, Pascal M, Bartra J, Picado C, Valero A, Kim DK, et al. Distinct transcriptome profiles differentiate nonsteroidal anti-inflammatory drug-dependent from nonsteroidal anti-inflammatory drug-independent food-induced anaphylaxis. J Allergy Clin Immunol (2016) 137(1):137-46. doi:10.1016/j.jaci.2015.05.042

62. Okayama Y, Hagaman DD, Metcalfe DD. A comparison of mediators released or generated by IFN-gamma-treated human mast cells following aggregation of
Fc gamma RI or Fc epsilon RI. J Immunol (2001) 166(7):4705-12. doi:10.4049/ jimmunol.166.7.4705

63. Woolhiser MR, Brockow K, Metcalfe DD. Activation of human mast cells by aggregated IgG through FcgammaRI: additive effects of C3a. Clin Immunol (2004) 110(2):172-80. doi:10.1016/j.clim.2003.11.007

64. Bruhns P. Properties of mouse and human IgG receptors and their contribution to disease models. Blood (2012) 119(24):5640-9. doi:10.1182/blood-2012-01-380121

65. Mancardi DA, Albanesi M, Jonsson F, Iannascoli B, Van Rooijen N, Kang X, et al. The high-affinity human IgG receptor FcgammaRI (CD64) promotes IgG-mediated inflammation, anaphylaxis, and antitumor immunotherapy. Blood (2013) 121(9):1563-73. doi:10.1182/blood-2012-07-442541

Conflict of Interest Statement: The authors declare that the research was conducted in the absence of any commercial or financial relationships that could be construed as a potential conflict of interest.

Copyright (c) 2017 Escribese, Rosace, Chivato, Fernández, Corbi and Barber. This is an open-access article distributed under the terms of the Creative Commons Attribution License (CC BY). The use, distribution or reproduction in other forums is permitted, provided the original author(s) or licensor are credited and that the original publication in this journal is cited, in accordance with accepted academic practice. No use, distribution or reproduction is permitted which does not comply with these terms. 